\title{
A study on impact of gender in investment decisions
}

\author{
D. Srijanani ${ }^{1, *}$, T. Vijaya ${ }^{2}$ \\ ${ }^{\mathbf{1}}$ Associate Professor, Vignana Jyothi Institute of Management Hyderabad, Telangana, ${ }^{2}$ Lecturer, Nizam College, Hyderabad, \\ Telangana, India
}

*Corresponding Author:

Email: dr.srijanani@vjim.edu.in

\begin{abstract}
John Grey's classic book "Men are from Mars, Women are from Venus" illustrates how they view the world through different lenses. Women differ from men in many ways including their attitude toward money. The literature supports the notion of gender differences in investing, pointing out that male investors are the more risk tolerant and self-confident investors. Yet few studies have empirically connected these conditions to differences in the information acquisition behavior of male and female investors. This paper examines the causes which make men and women to behave differently in financial matters. The paper also studies if there exists differences in the information source and is this the cause for women exhibiting greater financial risk aversion than men.
\end{abstract}

Keywords: Domestic Banks, Foreign Banks, Efficiency, Impact, Data Envelopment Analysis, Standard Deviation, Correlation.

\section{Introduction}

Financial decisions represent important part of individual's lives. Understanding the way, in which individuals make financial decisions, is very important. An investment is the sacrifice of certain present value for the uncertain future reward. An investor's background and past experiences can also play a significant role in the decisions an individual makes during the investment process.

Financial risk taking in investments could result in both negative like increasing debts and positive outcomes like making an investment profit.

John Grey's classic book "Men are from Mars, Women are from Venus" illustrates how they view the world through different lenses. Women differ from men in many ways including the aspects like attitude toward money. Women are more cautious and men are more risk friendly.

The literature supports the notion of gender differences in investing, pointing out that male investors are the more risk tolerant and self-confident investors. Yet few studies have empirically connected these conditions to differences in the information acquisition behavior of male and female investors. This paper examines if men and women behave differently in their investment decisions. The level of risk taken by the male and female investors is also examined in this paper. The paper also studies if there are differences in the information source and is this the cause for women exhibiting greater financial risk aversion than men.

\section{Review of Literature}

Katja Meier-Pesti and Elisabeth Goetze (2006) examined the effects of masculinity and femininity on the propensity to take financial risk. A random adult sample of 241 respondents was used in the study. In the first step, effects of gender identification and biological sex on masculinity and femininity were confirmed in an analysis of co-variance. In the second step, effects of gender salience and biological sex on risk taking were analyzed in an analysis of variance. The research showed that the difference between women and men in terms of masculinity had decreased.

Zuckerman and Kuhlman (2000) found in their study that "men engage in more overall risky behavior than women" and within financial matters Prince (1993) found that men perceive themselves as more competent.

Powell and Ansic (1997) found that gender is a important explanatory factor affecting confidence in investment decisions. Females were less confident about their decisions after controlling for factors such as age, experience, education, knowledge, and asset holdings. In such a study of financially orientated savers, Steinerock (1991) found that women had a lower risk preference and a higher degree of anxiety in financial decisions than men, plus a stronger desire to use financial advisors". This demonstrates through the research that given most circumstances regarding financial matters, women seek less risk than men.

Powell and Ansic (1997) argue, could be because of different investment strategies as men and women are motivated by different "needs". They put forward the idea that these different "needs" and therefore strategies, may be that women are looking more for security whereas men are looking for returns.

Overconfidence it is felt (Langer and Roth (1975), Miler and Ross (1975) and Taylor and Brown (1988) cited in Daniel, Hirshleifer and Subrahmanyam (1998)) is due to the misguided belief that one knows more than one does and that people give them more credit than is due when investment decisions turn out the way that was expected. However, when decisions don't turn out the way that they were intended, this is put down to external factors beyond the individual's control.

Matthew C. Sonfield, Robert N. Lussier and Joel Corman (1997) analyzed whether men and women have 
different strategic orientations and whether they differed in their strategic decision-making behavior. A random sample of 802 small businesses was surveyed by mail and follow-up telephone methods. The response rate was $20 \%$, with 151 usable sets of data. A chi-square test and a Mann-Whitney U test were used as statistical tools in this paper. The study shows that male and female entrepreneurs showed no differences in the strategies they choose to invest, and in their satisfaction with business performance.

Christiane Schwieren and Matthias Sutter (2003), there paper addressed the gender differences in trust. The study concluded that men trust more in the abilities of the people they interact with than women do.

There are many research papers supporting the idea that women have a lower level of confidence than men in their ability to make decisions, the present study intends to check if this is true and if the women make different investment choices than men.

\section{Objectives of the study}

The objectives of the study are

1. To examine if there exists any significant difference in the investment choice of men and women

2. To study if the information sources of men and women are different resulting in a difference in the investment choices they make.

\section{Sources of Data}

The data used for this paper is primary data and collected through the questionnaire. A pilot study was carried out with a sample of 10 respondents prior to conducting the actual survey. Ambiguous or unclear questions were rephrased. Convenient sampling method was used to select the respondents. The respondents were those who are investors in stock market and are not restricted to India or Andhra Pradesh. Out of 210 questionnaires distributed 108 correctly filled questionnaires were received. The data has been processed and analyzed by tabulated interpretation so that finding can be communicated easily.

To analyze the choice of investment avenues between males and females, Mann Whitney Rank Sum test was used. To study the risk-taking level among male and female, ANOVA was used in the study.

\section{Hypothesis}

Hypothesis 1: $\mathrm{H}_{0}$ There is no significant difference in the investment choice between male and female investors.

$\mathrm{H}_{1}$ There is significant difference in the investment choice between male and female investors

Hypothesis 2: $\mathrm{H}_{0}$ There is no significant difference in the risk-taking level between male and female.

$\mathrm{H}_{1}$ There is significant difference in the risk-taking level between male and female.

Hypothesis 3: $\mathbf{H}_{0}$ There is difference in the information sources between male and females.

$\mathbf{H}_{1}$ There is no significant difference in the information sources between male and females.

\section{Analysis and interpretation}

Classification based on gender and age

Table 1: Classification based on Gender and Age

\begin{tabular}{|l|c|c|c|c|}
\hline Age group & Female & Male & Grand Total & Percentage \\
\hline 16 - 25 years & 8 & 32 & 40 & $37 \%$ \\
\hline 26 - 35 years & 12 & 18 & 30 & $28 \%$ \\
\hline 36 - 50 years & 14 & 13 & 27 & $25 \%$ \\
\hline Above 51 years & 2 & 8 & 10 & $9 \%$ \\
\hline Grand Total & 36 & 72 & 108 & $100 \%$ \\
\hline
\end{tabular}

The gender and age wise classification of the investor profile of the respondents is given in Table 1 above. The table shows that the major part of the investors is between 36-50 years of age under female group and $16-25$ years for male. Among the age group of 36- 50 years, female investors do more investment or equal to male. In the age group of51 years and above, male respondents are more than the other counter part because at this age group women don't go for investment due to uncertainties. The least number of investors are found in the age group of above 51 years which implies that at this age people don't invest much in risky assets because of the various constraints. 


\section{Classification based on Gender and Educational Qualification}

Table 2: Classification based on Gender and Educational Qualification

\begin{tabular}{|l|r|r|c|c|}
\hline $\begin{array}{l}\text { Educational } \\
\text { qualification }\end{array}$ & Female & Male & $\begin{array}{l}\text { Grand } \\
\text { Total }\end{array}$ & Percentage \\
\hline Professional & 5 & 10 & 15 & $14 \%$ \\
\hline Post Graduate & 18 & 32 & 50 & $46 \%$ \\
\hline Undergraduate & 12 & 28 & 40 & $37 \%$ \\
\hline Secondary & 1 & 2 & 3 & $3 \%$ \\
\hline Grand Total & 36 & 72 & 108 & $100 \%$ \\
\hline
\end{tabular}

The gender wise and Educational Qualification classification of the respondents is depicted in Table 2. From the table it can be inferred that most of the investor are Post Graduates. 97\% of the investors are holding a bachelor's degree or more. The investors are educated and the percentage of graduate investors is more or less the same in both the genders. The investment choices made are include equity, mutual funds and commodities and the investors are aware of the investment choices.

\section{Investment choice between Gender Groups}

Hypothesis 1: $\mathrm{H}_{0}$ There is no significant difference in the investment choice between male and female investors.

$\mathrm{H}_{1}$ There is significant difference in the investment choice between male and female investors

Table 3: Group Statistics

\begin{tabular}{|l|c|c|c|c|c|}
\hline & Gender & $\mathbf{N}$ & Mean & Std. Deviation & Std. Error Mean \\
\hline $\begin{array}{l}\text { What sources of funds do } \\
\text { you utilize to invest in } \\
\text { stock market? }\end{array}$ & Male & 72 & 2.4583 & 1.22115 & .14391 \\
\cline { 2 - 6 } & Female & 36 & 2.4167 & 1.18019 & .19670 \\
\hline
\end{tabular}

\begin{tabular}{|c|c|c|c|c|}
\hline & Null Hypothesis & Test & Sig. & Decision \\
\hline 1 & $\begin{array}{l}\text { The distribution of What sources } \\
\text { funds do you utilize to invest in } \\
\text { stock maket? is the same across } \\
\text { categories of Gender. }\end{array}$ & $\begin{array}{l}\text { ofndependent- } \\
\text { Samples } \\
\text { pann- } \\
\text { whitney U } \\
\text { Test }\end{array}$ & .861 & $\begin{array}{l}\text { Retain the } \\
\text { null } \\
\text { hypothesis. }\end{array}$ \\
\hline
\end{tabular}

Given that our calculated significance value is (.861) and p value should be less than .05 , hence we accept the null hypothesis that there is no significant difference in investment choice between male and female investors.

\section{Level of Risk}

Hypothesis 2: $\mathrm{H}_{0}$ There is no significant difference in the risk-taking level between male and female. $\mathrm{H}_{1}$ There is significant difference in the risk-taking level between male and female.

Table 4: Group Statistics

\begin{tabular}{|l|l|c|c|c|c|}
\hline & Gender & $\mathbf{N}$ & Mean & Std. Deviation & Std. Error Mean \\
\hline \multirow{2}{*}{$\begin{array}{l}\text { What kind of investing / } \\
\text { trading do you adopt? }\end{array}$} & Male & 72 & 1.7917 & .62658 & .07384 \\
\cline { 2 - 6 } & Female & 36 & 2.1111 & .52251 & .08708 \\
\hline
\end{tabular}

\begin{tabular}{|c|c|c|c|c|}
\hline & Null Hypothesis & Test & Sig. & Decision \\
\hline 1 & $\begin{array}{l}\text { The distribution of What kind of } \\
\text { investing/trading do you adopt? } \\
\text { the same across categories of } \\
\text { Gender. }\end{array}$ & $\begin{array}{l}\text { Independent- } \\
\text { isamples } \\
\text { isuann- } \\
\text { whitney u } \\
\text { Test }\end{array}$ & .009 & $\begin{array}{l}\text { Reject the } \\
\text { null } \\
\text { hypothesis. }\end{array}$ \\
\hline
\end{tabular}

Asymptotic significances are displayed. The significance level is .05 .

Given that our calculated significance value is (.009) and $\mathrm{p}$ value should be less than .05 , hence based on our hypothesis, we reject the null hypothesis and accept the alternative hypothesis that there is a significant difference in risk taking level between male and female investors. 
Information sources of men and women are different resulting in a difference in the investment choices they make.
Hypothesis 3: $\mathbf{H}_{0}$ There is difference in the information sources \& investment choice between male and females. $\mathbf{H}_{1}$ There is no significant difference in the information sources \& investment choice between male and females.

Table 5: Group Statistics

\begin{tabular}{|l|l|l|l|c|c|}
\hline & Gender & $\mathrm{N}$ & Mean & Std. Deviation & Std. Error Mean \\
\hline $\begin{array}{l}\text { What sources of funds do you } \\
\text { utilize to invest in stock } \\
\text { market? }\end{array}$ & Male & 72 & 2.4583 & 1.22115 & .14391 \\
\cline { 2 - 6 } & female & 36 & 2.4167 & 1.18019 & .19670 \\
\hline $\begin{array}{l}\text { What information sources d } \\
\text { you use to trade in a particular } \\
\text { stock? }\end{array}$ & Male & 72 & 4.9861 & 2.75012 & .32411 \\
\cline { 2 - 6 } & female & 36 & 4.8056 & 2.76529 & .46088 \\
\hline
\end{tabular}

Hypothesis Test Summary

\begin{tabular}{|c|c|c|c|c|}
\hline & Null Hypothesis & Test & Sig. & Decision \\
\hline 1 & $\begin{array}{l}\text { The distribution of what souroes } \\
\text { funds do you utilize to invest in } \\
\text { stock market? is the same across } \\
\text { categories of Gender. }\end{array}$ & $\begin{array}{l}\text { of Independent- } \\
\text { Samples } \\
\text { hanian- } \\
\text { unhitney u } \\
\text { Test }\end{array}$ & $.8 B 1$ & $\begin{array}{l}\text { Retain the } \\
\text { null } \\
\text { hypothesis. }\end{array}$ \\
\hline 2 & $\begin{array}{l}\text { The distribution of what informa } \\
\text { sources d you use to trade in a } \\
\text { particularstooks is the same } \\
\text { across oategories of Gender. }\end{array}$ & $\begin{array}{l}\text { tiolpidependent- } \\
\text { hamples } \\
\text { whinitney u } \\
\text { Test }\end{array}$ & .542 & $\begin{array}{l}\text { Retain the } \\
\text { null } \\
\text { hypothesis }\end{array}$ \\
\hline
\end{tabular}

Given that our calculated significance value is (.0866) and (.749) $\mathrm{p}$ value should be ( $\mathrm{p}<.05)$, hence based on our hypothesis, we accept the null hypothesis and reject the alternative hypothesis that there is a significant difference information sources\& investment choice between male and female investors.

\section{Conclusion}

The main aim of the paper was to verify the role of gender in financial decision-making. The primary objective is to find out if gender differences exist in investment and risk-taking among male and female investors. The paper also checks if the difference is due to the difference in the information. Relatively, various hypotheses were created for the study and a primary study is carried out for a sample size of 210 respondents were 108 correctly filled up questionnaires were received.

This research provides evidence of risk taking difference between males \& females. The research supports that men are more risk taking than women. It is also observed that difference in the risk-taking capacities between men and women is observed in their choice of investment avenues. The analyses show that women prefer risk free investments, while men prefer risky investments. Women investors tend to display less confidence in their investment decisions and hence have lower satisfaction levels. The present study proves that the gender differences do impact the investment behavior. There is a significant difference in the level of risk taken by male and female investors. It is also observed that the information available to male and female investors is different and hence there is a difference in their investment decision.

\section{References}

1. Byrnes, James P.; Miller, David C.; Schafer, William D (1999). "Gender Differences in Risk-Taking",

Psychological Bulletin, Vol 125(3), pp. 367-383.

2. Barke Richard \& Paul Slovic (1997), "Risk Perception of Men and Women Scientists", Social Science Quarterly, Vol 78. Pp 167-176.

3. Christine R. Harris, Michael Jenkins and Dale Glaser, (2006). "Gender Differences in Risk Assessment: Why do Women Take Fewer Risks than Men?" Judgment and Decision Making, Vol.1, no.1, pp. 48-63.

4. Christiane Schwieren and Matthias Sutter, (2003). "Trust in cooperation or ability? An experimental study on gender differences," Issue October.

5. Dr.Monica Sharma, Dr.Vani Vasakarla.” An empirical study of gender differences in risk aversion and overconfidence in investment decision making," volume 2, Issue 7, July 2013.

6. Gaur Arti1, Julee, Sukijha Sunita (2011), Difference in Gender Attitude in Investment Decision Making In India, Research Journal of Finance and Accounting, Vol 2, No 12.

7. Katja Meier-Pesti and Elisabeth Goetze, (2006) Masculinity and Femininity as Predictors of Financial Risk-Taking: Evidence from a Priming Study on Gender Salience, European Advances in Consumer Research, Vol 7.

8. Kahneman, D. and Tversky, A. (March 1979) Prospect Theory: An Analysis of decision Under Risk, Econometrica, Volume 47, No.2, pp.263-291.

9. Kyle, A. S. and Wang, F. A. (December 1997) Speculation Duopoly with Agreement to Disagree: Can Overconfidence Survive the Market Test? The Journal of Finance, Vol. LII No.5 pp.2073- 2090. 
10. Matthew C. Sonfield, Robert N. Lussier and Joel Corman (1997), "Gender Differences in Strategic DecisionMaking: An Empirical Study of the Entrepreneurial" Strategy Matrix.

11. Madhurima deb and kavitha chavali." A study of gender differences in investment behaviour", Asia-Pacific Journal of Management Research and Innovation July 2009 vol. 5 no. $345-55$.

12. Odean, T. (December 1998) Volume, Volatility, Price, and Profit When All Traders Are above Average, The Journal of Finance, Volume LIII No.6, pp.1887-1934.

13. Powell, M. and Ansic, D. (1997) Gender differences in risk behaviour in financial decision making: An experimental analysis, Journal of Economic Psychology, 18 , pp.605-628.

14. Rita Martenson, (2008) "Are men better investors than women? "Gender differences in mutual funds and pension investments", Journal of Financial Services Marketing, Vol. 13, pp 72-81.

15. Sharpe, W. (1964) Capital asset prices: a theory of market equilibrium under conditions of risk, Journal of Finance, Vol. 19, pp.768-783.

16. Shiller, R. J. ("no date") Human Behaviour and the Efficiency of the Financial System, pp.134.www.econ.yale.edu.

17. Siva, (2012) "A Study on Gender Difference in Investment Choice \& Risk-Taking, IJAR-BAE Vol. 01. Issue 02. Article No.1

18. Tahira hira."Gender differnces in investment behaviour FINRA",Milestone 3 Report, august 31, 2006.

19. Tahira k.hira and cazila loibl." Gender differences in investment behavior ",

20. Handbook of consumer finance research 2008, pp 253270.

21. Www.link.springer. Com

22. Zuckerman, M. and Kuhlman, D. M. (December 2000) Personality and Risk Taking: Common Biosocial Factors, Journal of Personality, pp.999-1029. 